
(e) Unfinished and new business.
(f) Presidential address at annual meeting.
(g) Reading of papers on local subjects.
(h) Reading of papers on foreign subjects.
(i) Exhibitions and discussions of local material.
(j) Exhibition and discussion of foreign material.

PAPERS.

\title{
A New Species of Fruitfly Parasite from Java (Hymenoptera).
}

\author{
BY D. T. FULLAWAY.
}

\section{Biosteres javanus n. sp.}

o $4 \mathrm{~mm}$. long; head and thorax ochraceous; closely punctate, rather coarsely on the head, and clothed with silvery hairs; abdomen yellowish brown, impunctate; legs, mandibles and palpi luteous; antennae fuscous brown, vertex of the head and valves of the ovipositor fuscous. Head transverse, more than twice as wide as long, wide between the eyes, which are convex; ocelli arranged in an equilateral triangle on the vertex, the field being elevated and smooth with a circumferential groove, posterior ocelli almost vertical, ocelli to the eye nearly twice the distance from ocellus to ocellus; antennae fairly close together, further removed from the eye than from each other, the sockets deep with elevated rims, 40-segmented, the scape and pedicel stout, the flagellum filamentous; face convex, subcarinate, wider than long, receding below, clypeal fossae deep; cheeks fairly wide, mandibles stout, curved and apically toothed. Thorax robust, nearly as wide as the head and deeper than wide, mesothoracic scutum with parapsidal grooves very deep, converging and provided with large fossae; two slight submedian depressions anteriorly; prescutellar sulcus with 4 deep fossae; scutellum triangular; metanotum carinate in the middle and fossulate at the sides with an anterior and posterior smooth transverse band; propodeum irregularly areolate and somewhat rugose, stigmata small and round. Mesopleurae with a deep and fossulated sulcus. Abdomen ovate, somewhat compressed apically. Ist and 2nd tergites longitudinally striate and separated by a deep sulcus, ist tergite longitudinally bicarinate, the sides also strongly margined; following tergites smooth and shining with a transverse line of fine silvery hairs close to the posterior border; ovipositor exserted and longer than the abdomen. Legs rather slender. Wings hyaline, veins

- fuscous, radius in anterior wing arising at about the middle of the stigma, which is lanceolate, second abscissa somewhat shorter than the Ist transverse cubitus.

Proc. Haw. Entom. Soc., IV, No. 2, June, 1920. 
o $3.5 \mathrm{~mm}$. long, black, the face, orbits of the eye and antennae basally reddish brown to testaceous, legs, mandibles, palpi and sternites of the abdomen (extending on to the tergite of the and segment laterally and the posterior margin of the following segments) luteous.

Described from 19 females and 7 males (type, allotype and paratypes), reared at Buitenzorg, Java, from pupae of Dacus ferrugineus in fruits of Capsicum, by P. van der Goot, 10.8.18. Types in collection H. S. P. A. Exp. Sta., Honolulu.

\section{A New Species of Immigrant Termite from the Hawaiian Islands.}

BY MASAMITSU OSHIMA.

Of the Institute of Science, Government of Formosa.

In the following is given the record of an immigrant termite, which first appeared in Honolulu in 1913 and has succeeded in becoming firmly established there. Specimens were forwarded to me by Mr. D. T. Fullaway, Entomologist of the Hawaiian Board of Agriculture and Forestry. According to his information, it is doing considerable damage in the city of Honolulu, completely honeycombing wood-products and woodwork. It does not build mounds like many tropical species, but makes,its nest in or near the ground, using a considerable amount of soil ; it forms very large colonies; it builds covered passage-ways when it comes to the surface.

No doubt these are characteristic of the termites gromped in the genus Coptotermes, most formidable pests in wooden structures. After examining the specimens, I came to the conchsion that the present species is new to science, related very closely, however, to Coptotermes formosanus Shiraki, from Japan and Formosa. Up to the present, there is no record with regard to the occurrence of Coptotermes in the Hawaiian Islands. Therefore, it is reasonable to believe that it has been introduced from South America or the Orient, as susgested by Mr. Fullaway.

Proc. Haw. Entom. Soc., IV, No. 2, June, I920. 


\section{$2 \mathrm{BHL}$ Biodiversity Heritage Library}

Fullaway, David T. 1920. "A new species of fruitfly parasite from Java." Proceedings of the Hawaiian Entomological Society 4, 260-261. https://doi.org/10.5962/bhl.part.16144.

View This Item Online: https://www.biodiversitylibrary.org/item/39842

DOI: https://doi.org/10.5962/bhl.part.16144

Permalink: https://www.biodiversitylibrary.org/partpdf/16144

\section{Holding Institution}

Smithsonian Libraries

\section{Sponsored by}

Smithsonian

\section{Copyright \& Reuse}

Copyright Status: NOT_IN_COPYRIGHT

This document was created from content at the Biodiversity Heritage Library, the world's largest open access digital library for biodiversity literature and archives. Visit BHL at https://www.biodiversitylibrary.org. 